\title{
Large numbers of new bacterial taxa found by Yunnan Institute of Microbiology
}

\author{
JIANG $\mathrm{Yi}^{i^{*}}$, CAO YanRu ${ }^{1,2}$, ZHAO LiXing $^{1}$, TANG ShuKun ${ }^{1}$, WANG Yun ${ }^{3}$, LI WenJun ${ }^{1}$, \\ XU Ping ${ }^{1}$, LOU Kai ${ }^{3}$, MAO PeiHong ${ }^{3} \&$ XU LiHua ${ }^{1}$ \\ ${ }^{1}$ Yunnan Institute of Microbiology, Yunnan University, Kunming 650091, China; \\ ${ }^{2}$ College of Resource and Environment, Northwest A \& F University, Yangling 712100, China; \\ ${ }^{3}$ Key Laboratory for Microbial Resources in Special Environments, Xinjiang Academy of Agricultural Sciences, Urumchi 830000, China
}

Received August 27, 2010; accepted December 27, 2010

\begin{abstract}
Extreme environments, primeval forest, sea sediments and plants in China yielded members of a new suborder, Jiangellineae, a new family Sinobacteraceae, and 23 new genera of actinomycetes and other bacteria. Three suggestions were made for further discoveries of new actinomycetes. First, natural habitats such as old growth forests, and extreme environments, should be given sampling priority; second, culturing procedures need to be constantly improved to mimic natural habitats; third, less than $98.5 \%$ similarity of 16S rRNA sequence to that of a known species could be used as an indicator of a new species.
\end{abstract}

bacteria, new taxon, suborder Jiangellineae, family Sinobacteraceae

Citation: Jiang Y, Cao Y R, Zhao L X, et al. Large numbers of new bacterial taxa found by Yunnan Institute of Microbiology. Chinese Sci Bull, 2011, 56: 709-712, doi: 10.1007/s11434-010-4341-7

Extensive hypersaline and alkaline soils, deserts, and more than 100 salt lakes are found in Xinjiang Uyghur Autonomous Region, Qinghai and Gansu provinces, northwestern China. We collected 535 soil and lake sediment samples from these provinces and autonomous region between 1993 and 2008. Actinomycetes and other bacteria were isolated from these samples using dilution plate techniques involving 12 different media. Isolates were purified, and then identified using a polyphasic taxonomic approach.

Large numbers of new bacterial taxa were discovered from the isolates, described and published. Members of a new suborder, Jiangellineae [1], were found in primeval desert soil in Gansu Province (Figure 1). 16S rRNA signature nucleotides are at positions 127: 234 (G-C), 598: 640 (C-G), 672: 734 (G-C), 831: 855 (U-A), 833: 853 (G-C), 840: 846 (A-U), 950: 1231 (G-C), 952: 1229 (G-C), 955: 1225 (G-U), 986: 1219 (U-G) and 987: 1218 (C-G). This is the highest level bacterial taxon established by a Chinese

*Corresponding author (email: jiangyikm@ hotmail.com) microbiologist. We named the family Jiangellaceae within this suborder. The type genus is Jiangella Song et al. [2]. Members of 8 new genera, Yania [3], Myceligenerans [4], Zhihengliuella [5], Haloactinospora [6], Haloglycomyces [7], Amycolicicoccus [8], Yimella [9] and Sinococcus [10] were discovered in saline soil. Members of 6 new genera, Streptomonospora [11], Sediminimonas [12], Haloactinopolyspora [1], Alkalibacillus [13], Salinimicrobium [14] and Aidingimonas [15] were found in salt lakes and mines. We conclude that new bacterial taxa are surprisingly common in extreme environments, especially in hypersaline and alkaline habitats (Table 1).

There are extensive natural forests, which are wellprotected from the actions of humans, in and around Yunnan Province. Members of 3 new genera, Actinobispora [16], Actinomycetospora [17] and Planosporangium [18] were found in soil samples collected from tropical rain forest in Xishuangbanna, Yunnan. A member of a new genus, Naxibacter [19], was found in coniferous forest at an elevation of $3700 \mathrm{~m}$ in Lijiang, northwestern Yunnan. A 


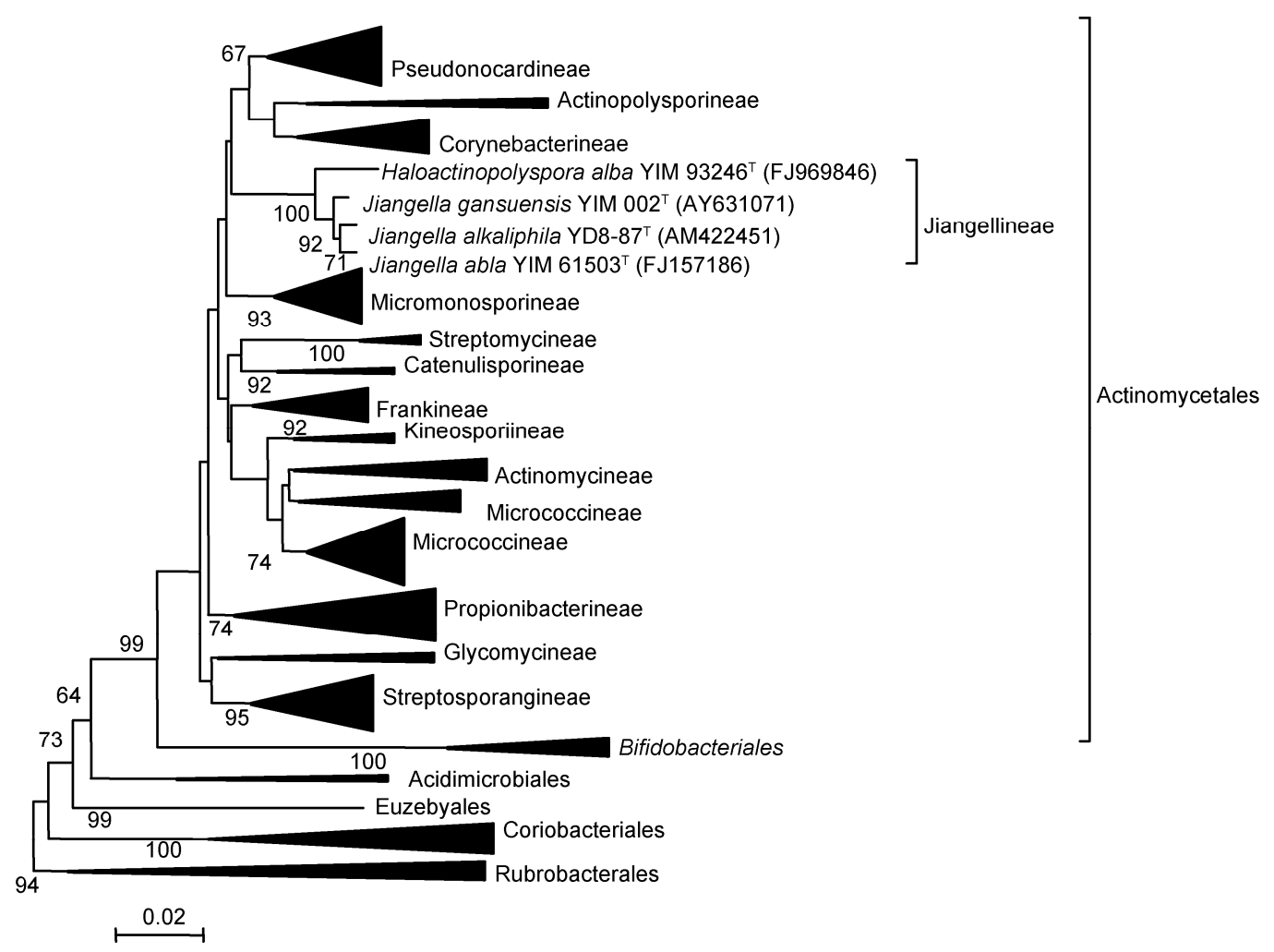

Figure 1 Phylogenetic position of strain YIM $93246^{\mathrm{T}}$ and members of the genus Jiangella within the class Actinobacteria based on 16S rRNA gene sequence analysis.

Table 1 Habitats of new bacterial taxa

\begin{tabular}{|c|c|c|}
\hline New taxon & Habitat & Reference \\
\hline \multicolumn{3}{|l|}{ New genera } \\
\hline Haloactinopolyspora & Salt lake sediments in Xinjiang & [1] \\
\hline Jiangella & Desert soil in Sunan, Gansu & [2] \\
\hline Yania & Saline soil in Xinjiang & [3] \\
\hline Myceligenerans & Alkaline salt marsh in Qinghai & {$[4]$} \\
\hline Zhihengliuella & Saline soil in Qinghai & [5] \\
\hline Haloactinospora & Hypersaline soil in Xinjiang & [6] \\
\hline Haloglycomyces & Hypersaline soil in Xinjiang & [7] \\
\hline Amycolicicoccus & Saline soil contaminated by crude oil in Xinjiang & [8] \\
\hline Yimella & Saline soil in Xinjiang & [9] \\
\hline Sinococcus & Saline soil in Qinghai & [10] \\
\hline Streptomonospora & Salt lake sediments in Xinjiang & [11] \\
\hline Sediminimonas & Ancient salt mines in Yunnan & [12] \\
\hline Alkalibacillus & Salt lake sediments in Qinghai & [13] \\
\hline Salinimicrobium & Salt lake sediments in Qinghai & [14] \\
\hline Aidingimonas & Salt lake sediments in Xinjiang & [15] \\
\hline Actinobispora & Natural forest in Weixin, Yunnan & [16] \\
\hline Actinomycetospora & Natural forest in Xishuangbanna, Yunnan & [17] \\
\hline Planosporangium & Natural forest in Menghai, Yunnan & [18] \\
\hline Naxibacter & Natural forest in Lijiang, Yunnan & [19] \\
\hline Plantactinospora & Root of Maytenus austroyunnanensis in Xishuangbanna, Yunnan & [20] \\
\hline Sciscionella & Sediments in northern South China Sea & [21] \\
\hline Marinactinospora & Sediments in northern South China Sea & [22] \\
\hline Sinobacter & Farmland soil polluted by chemicals & [22] \\
\hline New family & & \\
\hline Sinobacteraceae & Farmland soil polluted by chemicals & [23] \\
\hline
\end{tabular}


member of a new genus, Plantactinospora [20], was found in root tissue of Maytenus austroyunnanensis in Xishuangbanna, Yunnan. In addition, members of 2 new genera, Sciscionella [21] and Marinactinospora [22], were found in sediment samples collected from the northern South China Sea, and a member of a new family, Sinobacteraceae [23], and a new genus Sinobacter [22], were also found from farmland soil polluted by chemicals and considered an artificial extreme environment. In total, more than 120 new species of bacteria were isolated from western China. In the last 10 years, our laboratory has become a world leader in the discovery of new bacterial taxa.

Drugs such as antibiotics and anticancer agents have made enormous contributions to human life over the last 100 years. Actinomycetes are one of the groups of microorganisms that are key producers of antibiotics. About $75 \%$ of the antibiotics used in medicine and agriculture are produced by actinomycetes, and these the pharmaceutical development of, however, has met with tremendous difficulties in the past. One of the difficulties is avoiding retesting of known microbial species and compounds. Based on our research and that of others overseas, it appears that more than $90 \%$ of the microorganisms in the natural world have not yet been obtained in pure culture [24-26]. From genomic research, it is evident that every new microbial taxon has the potential to contain new genes or gene clusters that synthesize new secondary metabolites. Obtaining new microbial species, particularly those in new genera, families or orders, and finding ways to culture previously uncultured microorganisms, are key to the discovery of new compounds and the development of new drugs [27]. We believe that the challenge to develop the genetic resources of uncultured microorganisms using metagenomic procedures will be aided by the following.

First, in natural environments, as a result of evolution, organisms have formed communities in which composition, rate of change and numbers of microorganisms should be relatively stable [28]. In general, actinomycete diversity in natural forest (especially tropical rainforest) is more complex than in secondary growth forest. We isolated 26 genera from tropical rain forest in Xishuangbanna and 17 genera from primeval forest in Grand Shangri-La. In contrast, only 5 genera were isolated from secondary growth forest in the Emei and Qingcheng Mountains (Table 2) [28]. The microbial communities of soil are remarkably different between tropical rainforest and frigid forest, and different between soils, lake sediments, sea sediments and soils hot springs. It is worth emphasizing extreme environments that have extreme acidity, alkalinity, salt, radioactivity, heat (hot springs), or cold (Polar Regions and snowy mountains); we found unique microorganisms living in these environments. Members of 19 genera were isolated from hypersaline soil in Qinghai Province (Table 2). In the search for further microorganisms, samples should thus be collected from unique environments including natural forests and extreme environments including sea sediments, plant tissues and animal feces. As treasure-houses of microbial resources, these environments should be well-protected, as National Nature Reserves or National Parks using the appropriate legislative steps, just as we protect unique animal and plant species.

Second, selective isolation methods for microorganisms need to be continually improved, with consideration given to the microorganisms' habitats of origin. Culturing variables include medium composition (e.g., carbon and nitrogen, auxin, hormones, vitamins, inhibitors and salt concentrations), $\mathrm{pH}$ and temperature. $\mathrm{T} 3$ medium (cellulose $10 \mathrm{~g}$, casein $0.3 \mathrm{~g}, \mathrm{KNO}_{3} 0.2 \mathrm{~g}, \mathrm{CaCO}_{3} 0.02 \mathrm{~g}, \mathrm{FeSO}_{4} 0.01 \mathrm{~g}$, $\mathrm{NaCl} 150 \mathrm{~g}, \mathrm{KCl} 20 \mathrm{~g}, \mathrm{MgCl}_{2} \cdot 6 \mathrm{H}_{2} \mathrm{O} 30 \mathrm{~g}, \mathrm{MgSO}_{4} \cdot 7 \mathrm{H}_{2} \mathrm{O} 5 \mathrm{~g}$, $\mathrm{K}_{2} \mathrm{HPO}_{4} 1 \mathrm{~g}$, agar $20 \mathrm{~g}$, pH 7.5), was designed for isolation of halophilic bacteria. Using this medium, many new taxa including members of Amycolicicoccus, Haloactinopolyspora, Haloactinospora, Haloglycomyces, Sinococcus, Yimella, Zhihengliuella, Actinopolyspora, Saccharomonospora and Saccharopolyspora were isolated from samples of saline soil and lake sediments in Xingjiang and Qinghai. Numbers of unculturable taxa rise and fall, as new taxa are found, and new culturing methods continually developed.

Third, based on DNA-DNA hybridization and 16S rRNA sequencing of many bacteria, if there is $98.5 \%$ similarity

Table 2 Diversity of cultured actinomycetes in different habitats

\begin{tabular}{|c|c|}
\hline Area & Diversity of cultured actinomycetes \\
\hline $\begin{array}{l}\text { Secondary forest in Emei and } \\
\text { Qingcheng Mountains }\end{array}$ & Dactylosporangium, Mycobacterium, Nocardia, Promicromonospora, Streptomyces \\
\hline $\begin{array}{l}\text { Tropical rain forest in } \\
\text { Xishuangbanna }\end{array}$ & $\begin{array}{c}\text { Actinomadura, Actinoplanes, Actinopolymorpha, Agrococcus, Agromyces, Arthrobacter, Citricoccus, Dactylosporangium, } \\
\text { Friedmanniella, Kribbella, Lentzea, Microbacterium, Micromonospora, Mycobacterium, Nocardia, Nocardioides, Nono- } \\
\text { muraea, Oerskovia, Planosporangium, Promicromonospora, Pseudonocardia, Rhodococcus, Saccharopolyspora, } \\
\text { Sphaerisporangium, Streptomyces, Streptosporangium }\end{array}$ \\
\hline $\begin{array}{l}\text { Hypersaline soil } \\
\text { in Qinghai }\end{array}$ & $\begin{array}{c}\text { Alkalibacillus, Citricoccus, Corynebacterium, Isoptericola, Jiangella, Marinococcus, Myceligererans, Nesterenkonia, No- } \\
\text { cardiopsis, Prauserella, Rhodococcus, Saccharomonospora, Salinimicrobium, Sinococcus, Sinocurtobacterium, Strepto- } \\
\text { monospora, Streptomyces, Yania, Zhihengliuella }\end{array}$ \\
\hline
\end{tabular}


between the 16S rRNA sequences of a new isolate and a known species, the isolate has an $80 \%$ likelihood of being a new species [27]. Therefore, for any new isolate, part of the $16 \mathrm{~S}$ rRNA sequence (about $800 \mathrm{bp}$ ), should be determined, and $98.5 \%$ similarity could be defined as a reasonable boundary between species (Table 3) [29].

Table 3 Similarity of 16S rDNA sequence and possibility of new species [27]

\begin{tabular}{cc}
\hline Similarity of 16S rDNA sequence & Possibility of new species (\%) \\
\hline $99 \%$ & $20 \sim 30$ \\
$98.5 \% \sim 99 \%$ & 50 \\
$98 \% \sim 98.5 \%$ & $70 \sim 80$ \\
$97 \% \sim 98 \%$ & 90 \\
$95 \% \sim 97 \%$ & 100 New species \\
$95 \%$ & 100 New genus \\
\hline
\end{tabular}

This work was supported by the National Natural Science Foundation of China (30900002, 30600001 and U0932601), and the International Cooperative Program of the Ministry of Science of Technology (2006DFA33550). We thank Mr. Chen for his technical assistance.

1 Tang S K, Zhi X Y, Wang Y, et al. Haloactinopolyspora alba gen. nov. sp. nov., a novel halophilic filamentous actinomycete isolated from a salt lake in China, with proposal of Jiangellaceae fam. nov. and Jiangellineae subord. nov. Int J Syst Evol Microbiol, 2010, doi: 10.1099/ijs.0.021725-0

2 Song L, Li W J, Wang Q L, et al. Jiangella gansuensis gen. nov., sp. nov., a novel actinomycete from a desert soil in north-west China. Int J Syst Evol Microbiol, 2005, 55: 881-884

3 Li W J, Chen H H, Xu P, et al. Yania halotolerans gen. nov., sp. nov., a novel member of the suborder Micrococcineae from a saline soil in China. Int J Syst Evol Microbiol, 2004, 54: 525-531

4 Cui X L, Schumann P, Stackebrandt E, et al. Myceligenerans xiligouense gen. nov., sp. nov., a novel hyphae-forming member of the family Promicromonosporaceae. Int J Syst Evol Microbiol, 2004, 54: $1287-1293$

5 Zhang Y Q, Schumann P, Yu LY, et al. Zhihengliuella halotolerans gen. nov., sp. nov., a novel member of the family Micrococcaceae. Int J Syst Evol Microbiol, 2007, 57: 1018-1023

6 Tang S K, Tian X P, Zhi X Y, et al. Haloactinospora alba gen. nov., sp. nov., a halophilic filamentous actinomycete of the family Nocardiopsaceae. Int J Syst Evol Microbiol, 2008, 58: 2075-2080

7 Guan T W, Tang S K, Wu J Y, et al. Haloglycomyces albus gen. nov., sp. nov., a halophilic, filamentous actinomycete of the family Glycomycetaceae. Int J Syst Evol Microbiol, 2009, 59: 1297-1301

8 Wang Y N, Chi C Q, Cai M, et al. Amycolicicoccus subflavus gen. nov., sp. nov., an actinomycete isolated from a saline soil contaminated by crude oil. Int J Syst Evol Microbiol, 2010, 60: 638-645

9 Tang S K, Wu J Y, Wang Y, et al. Yimella lutea gen. nov., sp. nov., a novel actinobacterium of the family Dermacoccaceae. Int J Syst Evol Microbiol, 2010, 60: 659-663

10 Li W J, Zhang Y Q, Schumann P, et al. Sinococcus qinghaiensis gen. nov., sp. nov., a novel member of the order Bacillales from a saline soil in China. Int J Syst Evol Microbiol, 2006, 56: 1189-1192

11 Cui X L, Mao P, Zeng M, et al. Streptomonospora salina gen.nov., sp. nov, a new member of the family Nocariopsaceae. Int J Syst Evol Microbiol, 2001, 51: 357-363

12 Wang Y X, Wang Z G, Liu J H, et al. Sediminimonas qiaohouensis gen. nov., sp. nov., a member of the Roseobacter clade in the order Rhodobacterales. Int J Syst Evol Microbiol, 2009, 59: 1561-1567

13 Jeon C O, Lim J M, Lee J M, et al. Reclassification of Bacillus haloalkaliphilus Fritze 1996 as Alkalibacillus haloalkaliphilus gen. nov., comb. nov. and the description of Alkalibacillus salilacus sp. nov., a novel halophilic bacterium isolated from a salt lake in China. Int J Syst Evol Microbiol, 2005, 55: 1891-1896

14 Lim J M, Jeon C K, Lee S S, et al. Reclassification of Salegentibacter catena Ying et al. 2007 as Salinimicrobium catena gen. nov., comb. nov. and description of Salinimicrobium xinjiangense sp. nov., a halophilic bacterium isolated from Xinjiang province in China. Int J Syst Evol Microbiol, 2008, 58: 1438-1442

15 Wang Y, Tang S K, Lou K, et al. Aidingimonas halophila gen. nov., sp. nov., a moderately halophilic bacterium isolated from a salt lake. Int J Syst Evol Microbiol, 2009, 59: 3088-3094

16 Jiang C L, Xu L H, Yang Y R, et al. Actinobispora, a new genus of the order Actinomyctales. Int J Syst Evol Microbiol, 1991, 41: 526-528

17 Jiang Y, Wiese J, Tang S K, et al. Actinomycetospora chiangmaiensis gen. nov., sp. nov., a new member of the family Pseudonocardiaceae. Int J Syst Evol Microbiol, 2008, 58: 408-413

18 Wiese J, Jiang Y, Tang S K, et al. A new member of the family $M i$ cromonosporaceae, Planosporangium flavigriseum gen. nov., sp. nov. Int J Syst Evol Microbiol, 2008, 58: 1324-1331

19 Xu P, Li W J, Tang S K, et al. Naxibacter alkalitolerans gen. nov., sp. nov., a novel member of the family 'Oxalobacteraceae' isolated from China. Int J Syst Evol Microbiol, 2005, 55: 1149-1153

20 Qin S, Li J, Zhang Y, et al. Plantactinospora mayteni gen. nov., sp. nov., a member of the family Micromonosporaceae. Int J Syst Evol Microbiol, 2009, 59: 2527-2533

21 Tian X P, Zhi X Y, Qin Y Q, et al. Sciscionella marina gen. nov., sp. nov., a marine actinomycete isolated from a sediment in the northern South China Sea. Int J Syst Evol Microbiol, 2009, 59: 222-228

22 Tian X P, Tang S K, Dong J D. Marinactinospora thermotolerans gen. nov., sp. nov., a marine actinomycete isolated from a sediment in the northern South China Sea. Int J Syst Evol Microbiol, 2009, 59: 948-952

23 Zhou Y, Zhang Y Q, Zhi X Y, et al. Description of Sinobacter flavus gen. nov., sp. nov., and proposal of Sinobacteraceae fam. nov. Int J Syst Evol Microbiol, 2008, 58: 184-189

24 Rheims H, Sproer C, Rainey F, et al. Molecular biological evidence for the occurrence of uncultured members of the actinomycete line of descent in different environments and geographical locations. Microbiology, 1996, 142: 2863-2870

25 Zengler K, Toledo G, Rappé M, et al. Cultivating the uncultured. Proc Natl Aacd Sci USA, 2002, 99: 15681-15686

26 Pachter L. Interpreting the unculturable majority. Nat Method, 2007, 4: 479-480

27 Jiang Y, Cao Y R, Wiese J, et al. A new approach of research and development on pharmaceuticls from actinomycetes. J Life Sci, 2009, 3: $52-56$

28 Cao Y R, Jiang Y, Wang Q, et al. Diversity and some bioactivities of cultured actinomycetes in four areas in Sichuan and Yunnan. Acta Microbiol Sin, 2010, 50: 995-1000

29 Xu L H, Li W J, Liu Z H, et al. Actinomycete Taxonomy, Principle, Practice and Method. Beijing: Science Press, 2007

Open Access This article is distributed under the terms of the Creative Commons Attribution License which permits any use, distribution, and reproduction in any medium, provided the original author(s) and source are credited. 